\section{Military Technical College Kobry El-Kobbah, Cairo, Egypt}

\section{$9^{\text {th }}$ International Conference on Civil and Architecture Engineering ICCAE-9-2012}

\title{
Energy Efficient Hotels As a Step towards Sustainable Tourism in Egypt
}

\author{
G.B. Hanna* and Hend E. Farouh**
}

\begin{abstract}
Tourism plays a significant role in the economic situation of Egypt and there is growing commitment toward sustainable tourism development in Egypt. Progress has been made toward sustainable tourism, although much more work remains to be done.

This paper focuses only on energy efficiency as one of the most important criteria of sustainable hotels as a step towards sustainable tourism in Egypt. It summarizes the results of energy simulation analysis to determine the effectiveness of building characteris tics in reducing electrical energy consumption for hotel buildings in Egypt. Specifically, the impact on building envelope performance is investigated for different strategies such as window size (WWR), glazing type (SHGC) and building construction for two geographical locations in Egypt (Cairo and Alexandria). The energy savings in hotel buildings with 200 rooms for different Lighting Power Densities (LPD), Energy Input Ratios (EIR) and HVAC systems will be analyzed showing certain findings of practical si gnificance, e.g. that a Window-toWall Ratio of 0.20 with reasonably shaded windows decrease the total annual electricity use for hotel buildings by more than $20 \%$ in the two Egyptian locations.
\end{abstract}

Keywords: Green Hotel (GH), Sustainable Tourism (ST), Energy Efficiency (EE), Energy Simulation (ES), Window to Wall Ratio (WWR), Solar Heat Gain Coefficient (SHG), Projection Factor (PF), Lighting Power Density (LPD).

\section{Background}

The environment is the main base for the natural and cultural resources for attracting tourists' worldwide [1]. Therefore, the conservation of environmental resources is very necessary for the long-term success of tourism development.

In the early1990s number of publications appeared identifying environmental tourism approaches such as ecotourism, sustainable tourism and responsible tourism which were defined by The World Watch Institute as follows [2] :

- Sustainable tourism is the tourism that meets the needs of present tourist and host regions while protecting and enhancing opportunities for the future .

- Ecotourism is a responsible travel to natu ral areas that conserves the environment and improves the welfare of local people.

* Emeritus Professor; Building Physicist, HBRC, Cairo/gbhanna44@yahoo.com

** Senior Researcher, Architecture \&Housing Research Institute, HBRC, Cairo /hendfarouh@gmail.com 
- Responsible tourism is the tourism that maximizes the benefits to local communities, minimizes negative social \& environmental impacts, and helps local people conserves fragile cultures, habitats, and species .

The comparison between traditional tourism development and ecotourism development is shown in table (1).

Table 1. Comparison between Traditional Tourism Development and Ecotourism [3]

\begin{tabular}{|c|c|c|}
\hline $\begin{array}{c}\text { Comparison } \\
\text { Aspect }\end{array}$ & $\begin{array}{c}\text { Traditional Tourism } \\
\text { Development }\end{array}$ & Ecotourism Development \\
\hline Main Goal & Money Profit Driven & $\begin{array}{l}\text { Sustainable Economic Driven Including } \\
\text { Local Community Needs \& Social } \\
\text { aspirations and Environmental Economy }\end{array}$ \\
\hline $\begin{array}{l}\text { Enabling } \\
\text { Objectives }\end{array}$ & $\begin{array}{c}\text { Land Speculation \& } \\
\text { Community Exploitation }\end{array}$ & Land Nurturing \& Community Empowering \\
\hline $\begin{array}{l}\text { Planning } \\
\text { Strategy }\end{array}$ & $\begin{array}{c}\text { Enclave Development } \\
\text { (with Distinct Boundaries) }\end{array}$ & $\begin{array}{c}\text { Integrated Development with Macro \& } \\
\text { Micro Surroundings }\end{array}$ \\
\hline $\begin{array}{l}\text { Investment } \\
\text { Period }\end{array}$ & $\begin{array}{l}\text { Short to Medium Term } \\
\text { Investment }\end{array}$ & Long Term Investment \\
\hline $\begin{array}{l}\text { Investment } \\
\text { Strategy }\end{array}$ & $\begin{array}{l}\text { High Capital Investment to gain } \\
\text { max. profits through high guest } \\
\text { capacity, services \& prices }\end{array}$ & $\begin{array}{l}\text { Low-Medium Capital Investment to gain } \\
\text { max. profits through ecotecture, location, low } \\
\text { guest capacity, services \& prices }\end{array}$ \\
\hline $\begin{array}{l}\text { Financing } \\
\text { Resource }\end{array}$ & $\begin{array}{l}\text { Borrowing from anywhere } \\
\text { mostly banks, } \\
\text { Exported Profits }\end{array}$ & $\begin{array}{c}\text { Ethical financing, } \\
\text { Community Benefited Profits }\end{array}$ \\
\hline $\begin{array}{c}\text { Human } \\
\text { Resources }\end{array}$ & $\begin{array}{c}\text { Economic Priority (Imported or } \\
\text { Local) }\end{array}$ & $\begin{array}{c}\text { Local Community Priority (Local Stylish \& } \\
\text { Labor Intensive) }\end{array}$ \\
\hline $\begin{array}{l}\text { Material } \\
\text { Resources }\end{array}$ & $\begin{array}{l}\text { Economic Priority (Imported or } \\
\text { Local) }\end{array}$ & Local Ecology Priority \\
\hline $\begin{array}{l}\text { Developer } \\
\text { Type }\end{array}$ & $\begin{array}{c}\text { Overseas, Multi-national, } \\
\text { Consortiums }\end{array}$ & $\begin{array}{l}\text { Most Probably Local Individuals or Local } \\
\text { consortiums }\end{array}$ \\
\hline Politics & Exclusive, Ego Centric & Inclusive, Eco Centric \\
\hline $\begin{array}{l}\text { Tourists } \\
\text { Needs }\end{array}$ & International Common Luxury & $\begin{array}{l}\text { Comfortable Basic Needs, } \\
\text { or Local Environment/Culture Based Luxury }\end{array}$ \\
\hline $\begin{array}{l}\text { Attractions } \\
\text { Priority }\end{array}$ & $\begin{array}{l}\text { The Facility then the } \\
\text { Surroundings }\end{array}$ & $\begin{array}{l}\text { The Surroundings (Natural, Man-made and } \\
\text { the Community Culture) then the Facility }\end{array}$ \\
\hline
\end{tabular}

Tourism plays a

significant role in the economic situation of Egypt as shown in Table (1) so there is growing commitment toward sustainable tourism development in Egypt from both public and private sectors. Progress has been made toward greater public and private sector cooperation, although much more work remains to be done.

Table 2. Travel and Tourism Economic Data in Egypt [4]

\begin{tabular}{|c|c|c|c|c|}
\hline \multicolumn{2}{|c|}{$\begin{array}{c}2009 \text { Travel \& Tourism } \\
\text { Economy GDP }\end{array}$} & $\begin{array}{c}2009 \text { Travel \& } \\
\text { Tourism } \\
\text { Economy } \\
\text { Employment }\end{array}$ & $\begin{array}{c}\text { 2009 Visitors } \\
\text { Exports }\end{array}$ & $\begin{array}{c}\text { Travel \& Tourism } \\
\text { Average Economy GDP } \\
\text { Real Growth 2010-2019 }\end{array}$ \\
\hline Million US \$ & $\%$ & $\begin{array}{c}\text { Thousands of } \\
\text { Jobs }\end{array}$ & US \$ Million & $\%$ \\
\hline $26,763.3$ & 14.95 & $2,882.3$ & $12,223.7$ & 4.78 \\
\hline
\end{tabular}

Emissions from the tourism sector come from its different subsectors mainly air transport, car transport and accommodation, as shown in figure (1). 


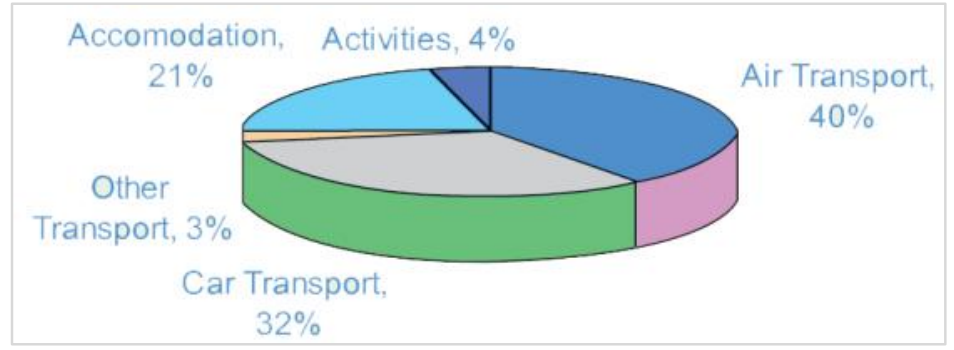

Fig. 1. Contribution of Various Tourism Elements to $\mathrm{CO}_{2}$ Emissions [5]

The accommodation is responsible for $21 \%$ of the $\mathrm{CO}_{2}$ emissions of the tourism sector. Hotels buildings is considered main item of the accommodation. The main criteria of sustainable hotel buildings are:

1. Cost effective to build \& practical to maintain;

2. Use natural resources and materials efficiently based on their life -cycle environmental impacts;

3. Conserve water, reduce runoff and treats waste -on site;

4. Maximize energy conservation and efficien cy;

5. Durable and long lasting;

6. Reduce building footprints, simplify building shapes and maximize space efficiency;

7. Apply passive design to optimize building orientation to integrate natural daylight and ventilation;

8. Healthy by eliminating toxic and harmful materials in facilities and surrounding environment;

9. Support transportation alternatives;

10. Reduce, reuse and recycle materials in all phases of construction and deconstruction;

11. Apply maintenance and operational practices that reduce or eliminate harm ful effects on people and environment, and

12. Design for future flexibility, expansion and capable of safe and efficient building demolition.

Since energy systems are an integral element of the design, construction and operation of all kinds of tourist facilities, the appropriate design and management of energy systems, particularly for efficient energy use, emissions and pollution reduction, and effective management of local resources, are of prime importance in promoting sustainable tourism development. In addition, systems that are designed, installed, or operated improperly can ruin the area's major tourist attraction: the environment. When the cost of energy and the potentially devastating environmental impact of an ill -planned tourist facility are added to the picture, the need for sound guidance on planning, designing, constructing, and operating such facilities becomes clear.

The studies shows that the main energy loads in hotels in Egypt are HVAC and cooling, lighting and water heaters with the auxiliary services, as shown in figure (2) which representing Electric energy consumption pattern of hotels in Port Said, Egypt.

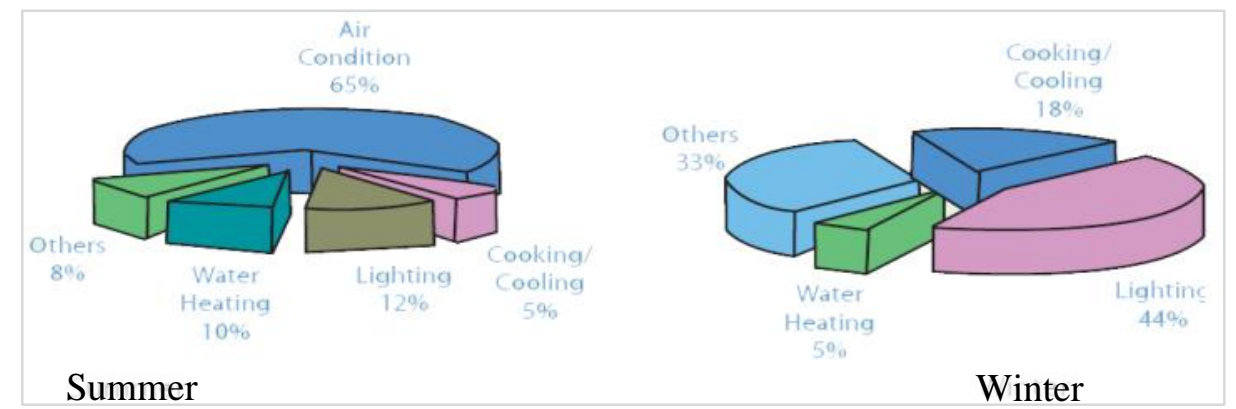




\section{Fig. 2. Electric Energy Consumption Pattern of Hotels in Port Said, Egypt [6]}

This paper will focus only on energy efficiency as one of the most important criteria of sustainable hotels as a step towards sustainable hotels and tourism in Egypt. A whole building simulation tool, DOE2Parm[7], is used to determine the effects of building parameters on the total electricity use for typical large hotel buildings.

\section{Modeling Description [8]}

The base case large hotel building model (named EG_LHOT) consists of 200-room hotel. It is a two-story podium block with support functions in the basement and a 20 floor tower with double-loaded corridors on each floor. The hotel consists of two main masses:

1) Tower: This mass contains the guest rooms and the immediate support services to the guest rooms, such as maid service, etc. There are 20 guest rooms on each floor, each of which is $4.5 \mathrm{~m}$ by $8.5 \mathrm{~m}$. Each facade has $103 \mathrm{~m}$ wide modules that contain 10 windows on each orientation.

2) Podium: This mass contains the lobby, restaurants, bars, shops, meeting rooms, plus the central support services. The ground floor of the podium block contains a lo bby, two levels of stores, administrative offices including a business center, store, lounge, public and private dining rooms, a coffee shop, kitchen, bakery, and general storage areas. The basement level of the podium contains a laundry, HVAC room, mainte nance room, staff locker and dining areas, and storage. The general configuration of the 200-room hotel can be seen in the DrawBDL image shown in Fig.1 the same parameters for hotel tower, also were used for the podium.

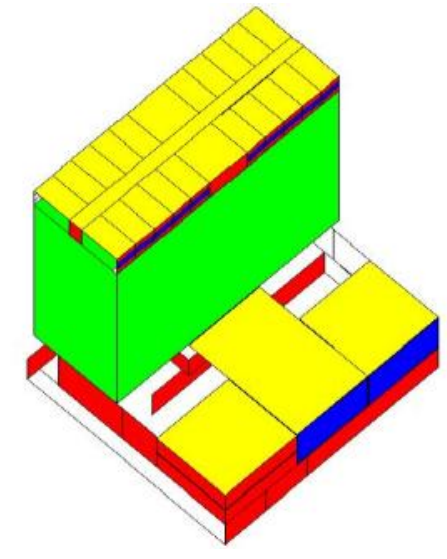

Fig. 1. The Simulated Hotel in Cairo with 200 Rooms

The EG_LHOT building model was simulated with the HVAC system SUM. The HVAC system is simply accumulates results from the loads program and only used when the envelope parameters are investigated.

The DOE2Parm simulation procedure was used in this study of typical hotel buildings in Egypt. Parametric inputs are provided by an MS Excel spreadsheet that is used to create a parametric input text file. Each row of the text file will generate a separate parametric run with a specific set of variables and script. Typical densities and schedules for hotel buildings are used to model occupancy, lighting, and equipment. For the entire hotel building floors, 
fluorescent luminaries were used to represent standard commercial installations. Li ghting power density was set at $15 \mathrm{~W} / \mathrm{m}^{2}$. Typical Egyptian hotel building occupancy schedules are used to define the operation patterns for the electrical lighting system. The base case inputs for different building and HVAC conditions are listed in Table 3.

Table 3. Base Case Parametric Inputs for The Simulated Hotel

\begin{tabular}{|c|c|c|c|c|c|}
\hline No & Parameter & Value & No & Parameter & Value \\
\hline 1 & Analysis Type & tower & 17 & Cool_SPT_Podium & 20 \\
\hline 2 & Number of Rooms & 200 & 18 & HEAT_SPT & 21 \\
\hline 3 & Orientation & $\mathrm{n}$ & 19 & Max_SUP_Temp & 40 \\
\hline 4 & Wall Construction & 12cm_brick & 20 & Min_SUP_Temp & 10 \\
\hline 5 & Wall_Insulation & none & 21 & Outair_Person & 10 \\
\hline 6 & Wall_Absorptance & 0.7 & 22 & COOL_CTRL_TYPE & constant \\
\hline 7 & Window_Type & 1p_shgc_61 & 23 & FAN_CTRL_TYPE & Constant \\
\hline 8 & Wwr_Tower & \begin{tabular}{|l|}
0.4 \\
\end{tabular} & 24 & SYS_TYPE & $\mathrm{fpfc}$ \\
\hline 9 & EX_SHADE_OH_PF & 0 & 25 & Baseboard_Source & electric \\
\hline 10 & EXT_SHADE_FIN_PF & 0 & 26 & Chiller_Type & herm-cent-chlr \\
\hline 11 & Roof_Insulation & none & 27 & Chiller_Size & -290 \\
\hline 12 & Roof_Absorptance & 0.7 & 28 & NBR_Chillers & 2.0 \\
\hline 13 & LPD & medium & 29 & Chiller_EIR & 0.22 \\
\hline 14 & Daylight & no & 30 & CHLR_HEAT_REJECT & air \\
\hline 15 & Equipment & medium & 31 & Tower_WBT & 29.0 \\
\hline 16 & Cool_SPT_Tower & 23 & 32 & Thermal_Comfort & no \\
\hline
\end{tabular}

\section{Parametric Analysis}

The analysis presented in this paper encompasses common types of modern hotel buildings. The Window-to-Wall Ratio (WWR) was varied from 0.0 (no openings) to 0.9 (glazed walls). Due to the vast selection of windows, Solar Heat Gain Coefficients (SHGC) for five different glazing types are specified with varying light transmittance were selected and analyzed. The intent was to obtain a wide range of transmittance values to get a broad representat ion of available products in Egypt. Parametric analyses have been conducted for key energy variables for the large hotel building, across typical ranges of values. The variables analyzed are: 1) building orientation; 2) roof insulation (top floor); 3) wall construction and insulation; 4) curtain wall, with rigid insulation; 5) mass wall, $12 \mathrm{~cm}$ brick, rigid insulation on 'outside' between brick and outside mortar layer; 6) Window-to-Wall Ratio (WWR); 7) glass type and Solar Heat Gain Coefficient (SHGC); 8) Solar shading using overhangs and fins ; 9) Lighting power density (LPD), and 10) HVAC System type. The results and possible implications are discussed.

\section{Building orientation}

The Base Case for the large hotel building in Egypt uses North orientation as sho wn in Figure 2. Since the building being studied has a $2: 1$ aspect ratio, this means that when $\mathrm{N}$ is specified, the long sides face N/S. Conversely, when $\mathrm{E}$ is specified, the long sides face E/W. The parametric analysis has been done for eight orienta tions for Cairo and Alexandria. The results are shown in Fig 2. The analysis was done for one façade building at mid -floor, and for the 
whole building. The figure indicates that hotel building with aspect ratio of $2: 1$ with N/S orientation will use $22 \%$ less energy than the same building with long sides facing E/W.

\section{Roof absorptance}

The value of roof absorption was changed from 0.3 (light color) to 0.7 (dark color) as shown in Fig.3. The results indicates that the color of the roof surface has great influence on the total energy consumption by about $4 \%$ and has great influence on Alexandria than Cairo by about $5 \%$.

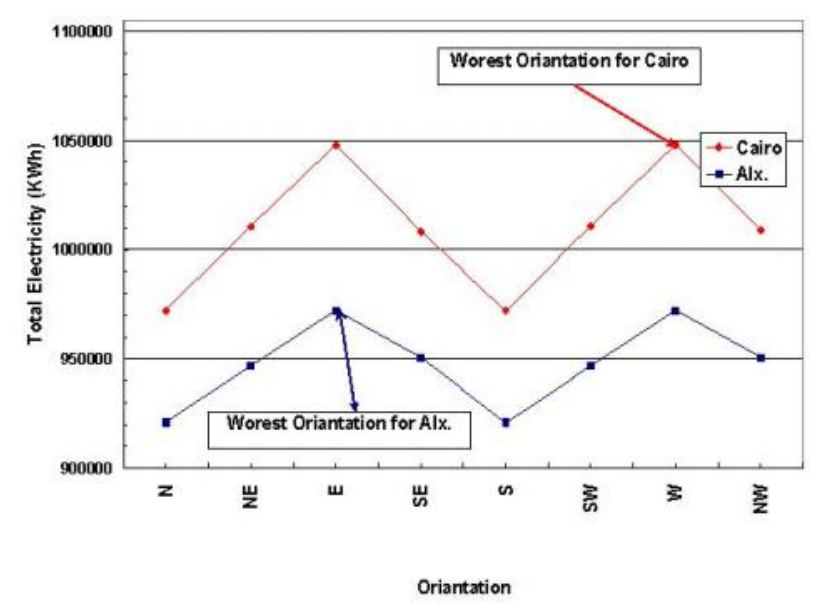

Fig. 2 Effect of building orientation

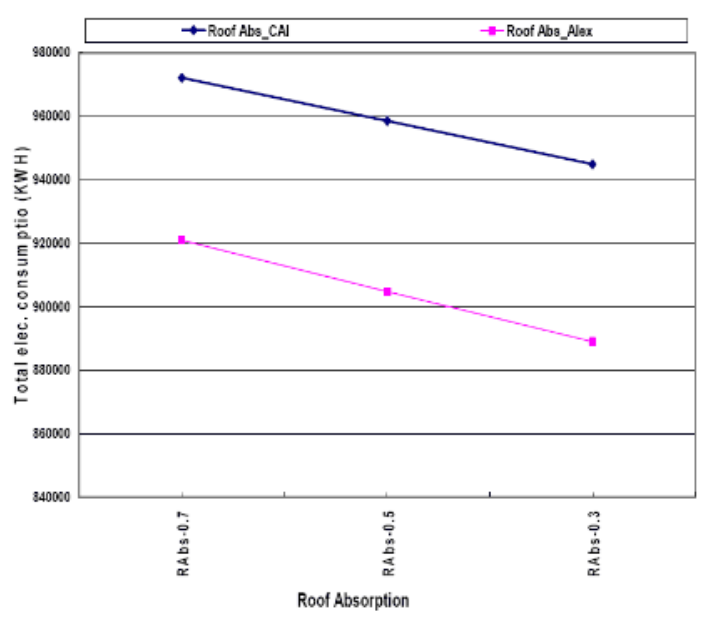

Fig. 3 Effect of roof absorptivty

\section{Roof insulation}

A single concrete roof construction was examined. Four insulation options were examined: 1 ) rigid polystyrene (25\& 50mm thick), 2) Celton (150mm), 3) Perlite (25 mm) and 4)

vermiculite ( 25 thick). The resulting annual energy results are shown in Figure 4 . The results indicate that the use of $75 \mathrm{~mm}$ of polystyrene roof insulation has the largest savings, but the difference in the total electricity used between $75 \mathrm{~mm}$ and $50 \mathrm{~mm}$ of polystyrene is very small. Annual electricity saving of $30 \%$ has been found for Cairo, and $22 \%$ for Alexandria. The same saving in the total electricity use could also be reached, using ether 150mm_of Celton, or $50 \mathrm{~mm}$ of Perlite.

\section{Wall construction}

Three types of construction were examined : Curtain wall, CMU and $120 \mathrm{~cm}$ thick brick.

(1) Curtain wall: With aluminum or glass on the outside, insulation, an air space, then a layer of gypsum board on the inside.

(2) 12cm_Mass wall: Hollow clay brick of $12 \mathrm{~cm}$, with mortar on both sides.

(3) 12_CMU: Concrete massive unit with mortar on both sides.

The energy results shown in Fig.5 indicate that the use of $12 \mathrm{~cm}$ brick has much more impact than the curtain wall or $12 \mathrm{~cm}$ CMU.
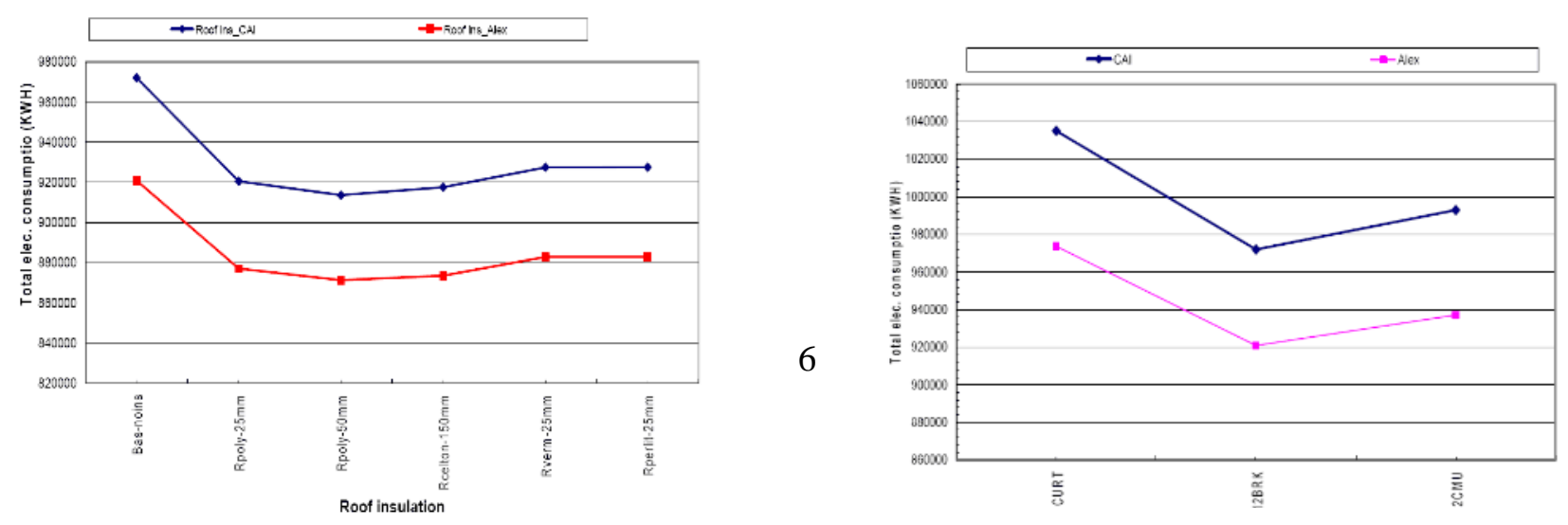


\section{Window-to-Wall Ratio (WWR)}

The Window-to-Wall Ratio (WWR) is the ratio of the total glass area to the total building wall area (including the glass) for all elevations of the building together. The WWR directly affects the amount of solar heat gain en tering the building, and thus has a large impact on the energy consumption of the whole building. The base case (BC) large hotel building has a $\mathrm{WWR}=0.4$. For the parametric analysis, this variable has been changed across a wide range of values from 0.1 to 0.9 . The resulting annual energy results are shown in Fig 6 . The results illustrate that increasing the WWR increases the total electricity consumption significantly.

\section{Glass Type: Solar Heat Gain Coefficient}

The base case large hotel building is modeled w ith a glass type of 1P_SHGC_61, which is single-pane glass with a Solar Heat Gain Coefficient of 0.61. In the parametric analysis, the SHGC has been changed across a wide range. All nine fenestration options use regular aluminum frames with no thermal brea ks. Four of the nine options are single pane, while two are double-paned. The double-pane options have a low emissivity coating on the inside pane

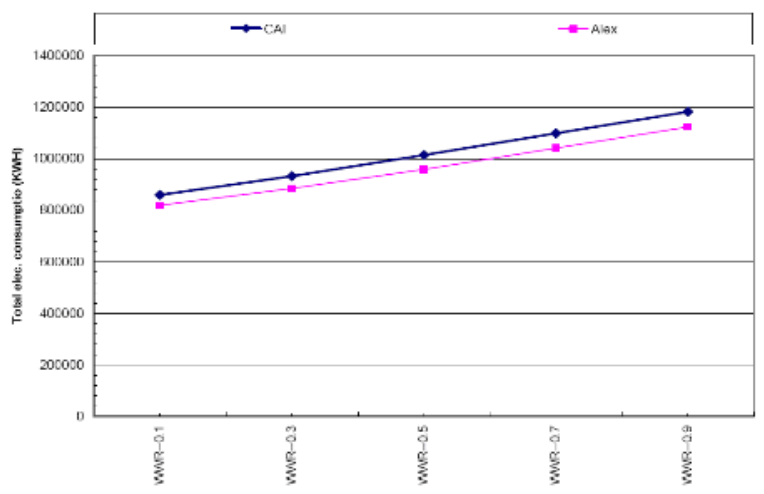

Fig. 6 Effect of Window-to-Wall Ratio (WWR)

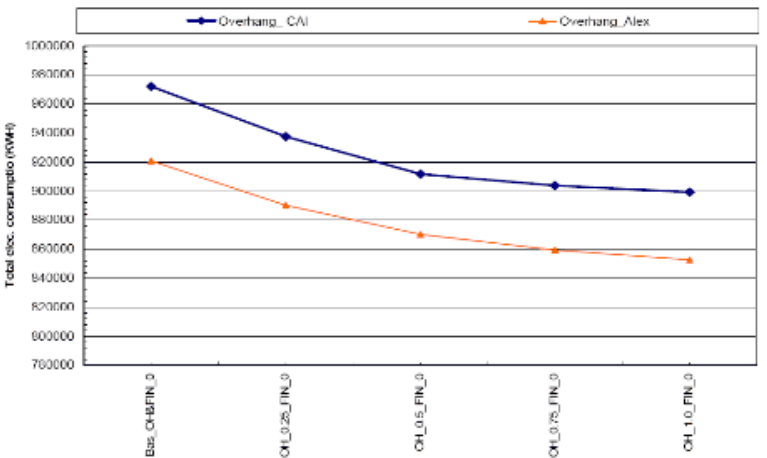

Fig. 7 Effect of overhang shading

of glass, [9].

The resulting annual energy results are shown in Fig 8 . These indicate that the type of glass used in large office buildings is an important variable. The range of SHGC values examined changed the total building electricity use by $20 \%$. In Cairo, reducing the SHGC from 0.81 to 0.23 will reduce the total electricity use by $20 \%$ and $18 \%$ in Alexandria.

\section{Solar Shading: Overhangs \& Fins}

The base case large hotel building in Egypt has been modeled with the following values $(0,0.25,0.5,0.75,1.0)$ for both overhang projection factor and fins. In addition, the building is modeled with two different orientations. The resulting annual energy results for overhangs 
and fins are shown in Fig. 9. The results indicate that the projection factors of overhang and fin as an important variable and can produce 6\%-18\% annual energy reduction depending on the building location, orientation and the type of exterior shading.

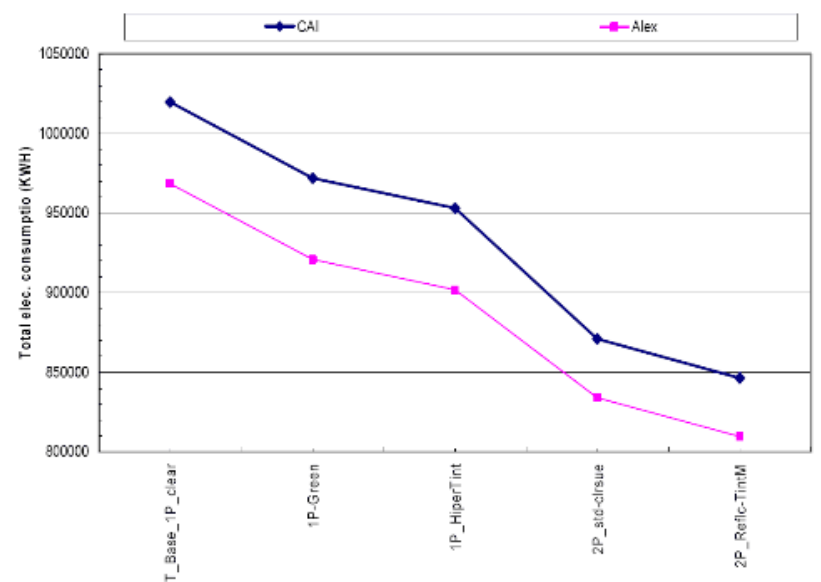

Fig. 8 Effect of Window Glass Type

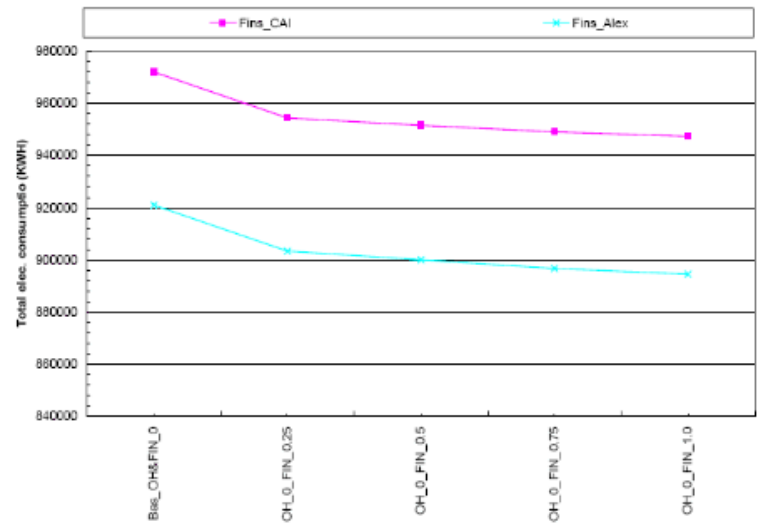

Fig. 9 Effect of Solar Shading

\section{Installed lighting Power Density (LPD)}

Lighting Power Density (LPD) is another major part of energy consumption in hotel buildings. This section investigates the magnitude of in fluence of lighting power density on the building consumption. The base case large hotel uses $15 \mathrm{~W} / \mathrm{m}^{2}$, which has been varied between 0 to $30 \mathrm{~W} / \mathrm{m}^{2}$ in the parametric analysis. The annual energy results obtained are shown in Fig 10. The results indicate that the LPD has a great impact on the annual energy use of hotel buildings. The energy consumption increased by about $80 \%$ when the light power level was increased from 5 to $25 \mathrm{~W} / \mathrm{m}^{2}$

\section{Air-Conditioning Systems (HVAC)}

Five different HVAC system types have been an alyzed: SUM, RESYS (Residential System), PSZ (Package Single Zone), TPFC (Two Pipe Fan Coil), and VAV (Variable Air Volume). In Egypt, the two most common HVAC systems are the PSZ and TPFC. For the analysis described earlier on the envelope and lighting lo ads, we have used the SUM system, which tallies the loads on the HVAC system but does not include any system efficiency consideration. HVAC system selection can have a significant impact on building energy use, often producing total annual energy use varia tions in the range of $30 \%$, as shown in Figure 11.

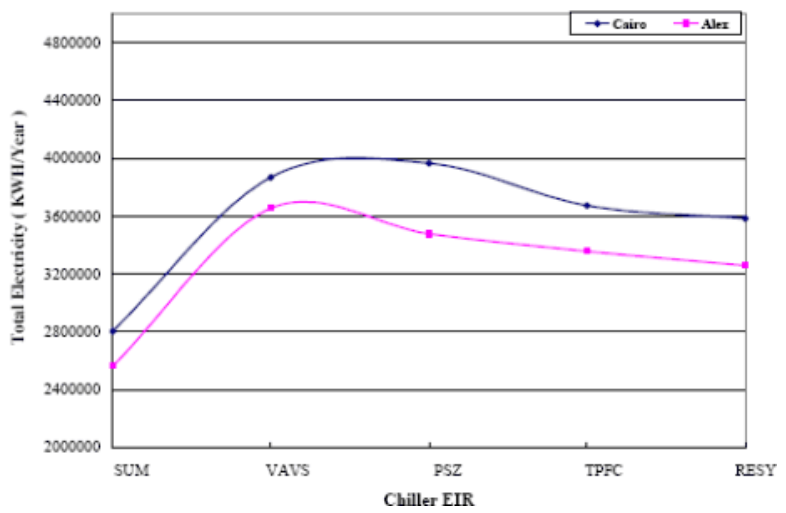




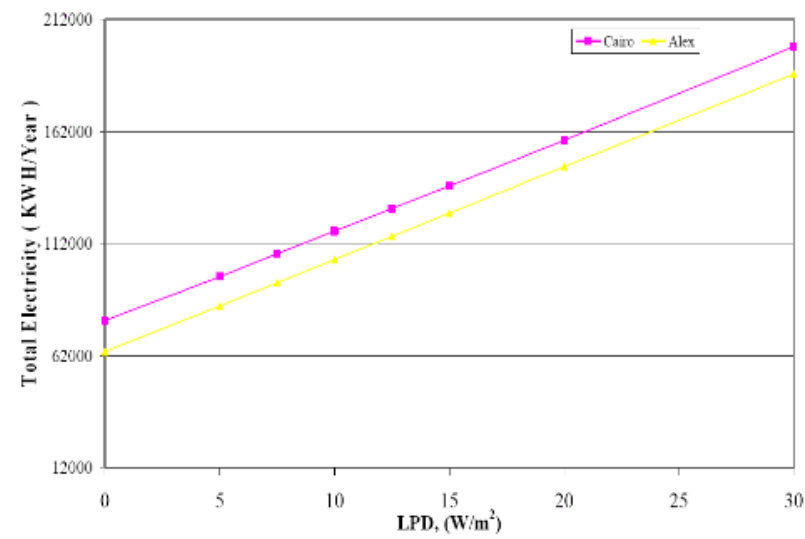

Fig. 10 Effect of LPD

\section{CONCLUSION}

The energy consumption of large hotel buildings are major part of energy usage in Egypt, and this study reaches to significant findings results. A "base case" large hotel building ("EG_LHOT") was defined, and sets of potential energy saving measures are determined. The energy saving of each of these measures based on DOE-2 parametric simulations,

are shown in Fig.12. The estimated results illustrates a considerable energy savings would reached by (1) starting with the base case large hotel building that represents current practice , and then (2) changing the key energy-related features to comply with the requirements of the energy code. The items that were identified include: 1) roof insulation; 2) wall insulation; 3) Window-to-Wall Ratio (WWR); 4) Lighting Power Density; 5) Chiller type; and 6) Glass Type (Solar Heat Gain Coefficient -SHGC). The essence of this paper has illustrated how significant energy saving in large hotel buildings can be achieved by judiciously selecting

with design loads.
Energy Saving of diffrent measure Hotel

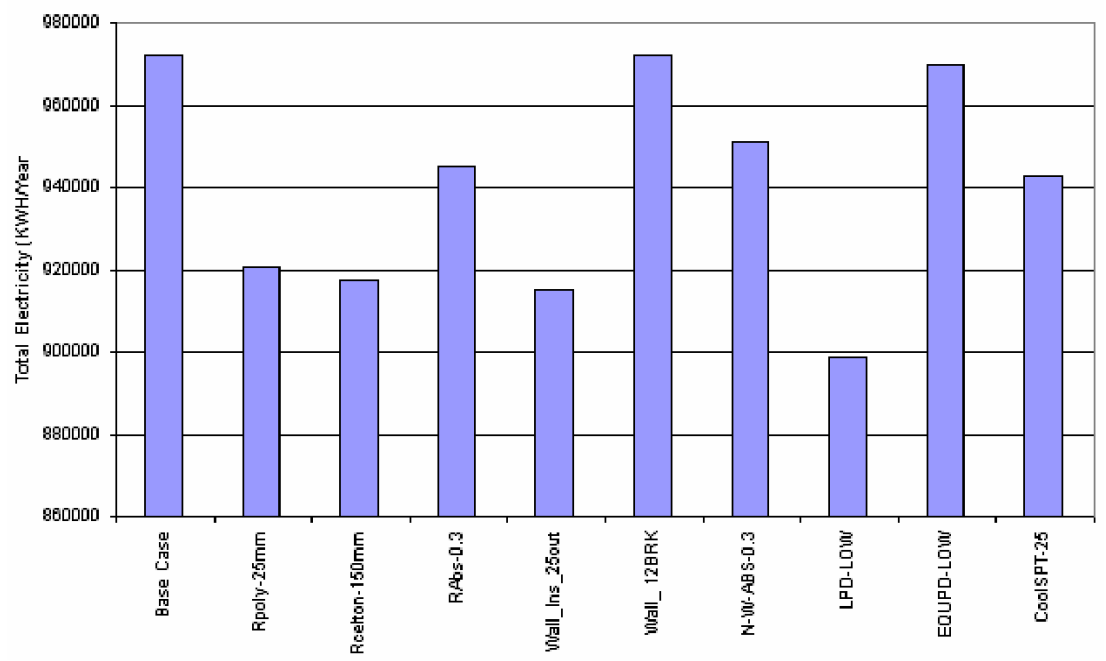

materials appropriate technique of windows, HVAC system and

Fig. 12 Energy savings of different measures

It can be concluded that developers, planners, designers should set a strategy on the sustainability, environment and e nergy approach. They should look at a "systems approach" in making design decisions. The strategy should target developing a facility that is integrated within itself and its environment, while satisfying guest comfort, access to energy and water services as well as reduced operating costs. 
In their role as the main strategic decision makers, the developers should encourage the designers to:

1. Adopt a "Green Building" approach, where the architectural design is integrated with the building's energy systems de sign to minimize wastes and emissions.

2. Upgrade energy use efficiency, through passive building designs, smaller modular power units and energy efficient fittings.

3. Evaluate competing options, to select the least-cost, efficient and sustainable options.

4. Adopt the use of "Green" energy sources like wind, solar and geothermal energy.

5. Incorporate passive measures as appropriate in the building design.

6. Adopt the usage of any type of energy efficiency measure including occupation cards, efficient lighting, daylight use and wall colors.

7. Adopt new technologies to reduce energy use including photocells, sheer curtains, occupancy sensors (motion detectors) and photovoltaic poles.

8. Evaluate the possibility of waste heat recovery systems on large generating units, laundry, etc.

9. Use solar water heating systems as appropriate.

10. In an already established hotel, energy audit is an essential step towards the establishment of a professional energy -management program.

\section{References}

[1] Bonn, M. A., Joseph, S. \& Dai, M., “An empirical analysis of ecogeneralists visiting Florida: 1998-2003”, 2005

[2] TIES, International Ecotourism Society. "TIES Global Ecotourism Fact Sheet", TIES, Washington, DC, 2006

[3] Salama, A., "Ecolodges: A Futuristic Epic for Ecotourism Development in Egyp t", Ecolodge Forum, TDA, Cairo, 2000

[4] ESCWA, "Guidelines for Energy Efficiency in the Tourism Sector", 2009

[5] "Climate change and tourism: responding to global challenges", world tourism organization and the United Nations environment program, 2008

[6] Ibrahim Abdul-Jalil, "Energy Efficiency in the Tourism Sector”, Case of Egypt, 2003

[8] PA Consultant Group, DC, USA, the Deringer Group, Berkeley, CA, USA

[7] Hanna G. B., Farouh H., "Energy Standard for New Hotel Buildings in Egypt", World Renewable Energy Congress IX, Florence, Italy, August 2006

[8] George B. Hanna, Hend Farouh, Energy Standard for New Hotel Buildings in Egypt, World Renewable Energy Congress IX, Florence, Italy, August 2006

[9] Conditioning Engineers, Atlanta, GA., ASHRAE, "Handbook of Fundamentals", ASHRAE, Atlanta, GA, 1999.

[10] "Energy Efficiency Residential Building Code", Ministry of Housing, HBRC, Egypt, 2003.

[11] Residential Energy Survey and Environmental Indicators in Great Cairo, Cairo University, (ECEP/DRTPC) and Organization Energy Planning (OEP), 2000 